\title{
Effects of temperature on the expression of redox genes in human dermal fibroblasts
}

\section{OYuji Katsuta, Misato Sugahara (Shiseido Global Innovation Center)}

\section{Introduction}

While core temperature of human bodies is maintained around $37^{\circ} \mathrm{C}$, skin temperature is subject to the environment and changes at a wide range. Skin surface temperature is $33^{\circ} \mathrm{C}$ and lower than the core temperature in normal condition. Especially skin temperature of legs can be very low in cold winter.

Temperature is very important to the human common cells and only a few degrees of change from $37^{\circ} \mathrm{C}$ will have negative effects on the cells. However, the effect of temperature on skin cells has not been fully investigated. In order to elucidate the effects of low temperature on dermal fibroblasts, the effects of culture temperature on the gene expressions of dermal fibroblasts were investigated. In this study, effects on redox-related genes were targeted.
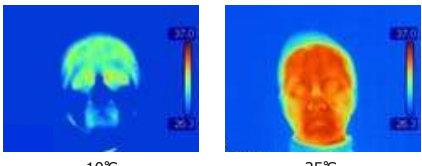

$10^{\circ} \mathrm{C}$

\section{Fig. 1 Facial skin temperature in different room temperature}

\section{Methods}

(1) Proliferation assay of dermal fibroblasts

$1 \times 10^{4}$ cells of normal human dermal fibroblasts (new born) were seeded in each well of 6-well plates, and cultured in DMEM with $10 \%$ FBS at $37^{\circ} \mathrm{C}$ for 24 hours. Then the plates were transferred to $30^{\circ} \mathrm{C} \sim 42^{\circ} \mathrm{C}$. After 0,3 , and 6 days, the cells were trypsinized and the numbers of the cell were counted.

(2) Quantification of gene expression of redoxfactors

$3 \times 10^{5}$ cells of normal human dermal fibroblasts (new born) were seeded in each well of 6-well plates, and cultured in DMEM with $10 \%$ FBS at $37{ }^{\circ} \mathrm{C}$ for 24 hours. Then the plates were transferred to $30{ }^{\circ} \mathrm{C} \sim 37{ }^{\circ} \mathrm{C}$. 24 hours later, RNA was prepared by RNeasy Mini Kit (Qiagen)

$3 \times 10^{5}$ cells of normal human dermal fibroblasts (new born) were seeded in each well of 6 -well plates, and cultured in DMEM with $10 \%$ FBS at $37{ }^{\circ} \mathrm{C}$ for 24 hours and transferred to $33{ }^{\circ} \mathrm{C}$ and cultured for 24 hours. Then the plates were transferred to 3 $\sim 42{ }^{\circ} \mathrm{C} .0,1,2,4,6$, and 12 hours later, RNA was prepared by RNeasy Mini Kit.

From the collected RNA, CDNA was synthesized by SuperScript $\circledast$ VILO ${ }^{T M}$ CDNA Synthesis Kit (Invitrogen). Then expression level of the following redox-related genes were quantified by $\mathrm{qPCR}$.

Thioredoxin Reductase 1 (TXNRD-1)

NAD(P)H Quinone Dehydrogenase 1 (NQO1)

Glutathione-Disulfide Reductase (GSR)

Thioredoxin (TXN)

Nf-E2 Related Factor 2 (Nrf-2)

\begin{tabular}{|c|c|c|}
\hline & $\begin{aligned} & \mathrm{HO}-1 \\
& \mathrm{NQO} 1 \\
& \mathrm{GSR}\end{aligned}$ & Anti-oxidative effects \\
\hline $\begin{array}{l}\text { Transcription } \\
\text { factor }\end{array}$ & $\begin{aligned} & \text { TXN } \\
& \text { TXNRD-1 } \\
& \text { Redox factors }\end{aligned}$ & $\begin{array}{l}\text { Prevent cellular damage } \\
\text { from oxidative stress } \\
\text { such as UV }\end{array}$ \\
\hline
\end{tabular}

(3) Thioredoxin reductase activity assay

Dermal fibroblasts were cultured at $30{ }^{\circ} \mathrm{C}$ or $37{ }^{\circ} \mathrm{C}$ for 24 hours. Activity of thioredoxin reductase was evaluated by using " Thioredoxin Reductase Activity Colorimetric Assay Kit "
(bioVision)

(4) Detection of Reactive Oxygen Species

Dermal fibroblasts were cultured at $30{ }^{\circ} \mathrm{C}$ or $37^{\circ} \mathrm{C}$ for 24 hours. Oxidative stress in live cells was measured by using CellROX® Green Reagent. After adding CellROX® Green Reagent into the culture medium, cells were incubated at $37^{\circ} \mathrm{C}$ for $30 \mathrm{~min}$. Then cells were fixed with formalin and fluorescence was observed under a microscopy.

\section{Results}

(1) Effects of culture temperature on the cell proliferation rate of dermal fibroblasts

Culture temperature of dermal fibroblasts was shifted from $37{ }^{\circ} \mathrm{C}$ to $30,33,37,40$, or $42{ }^{\circ} \mathrm{C}$. The numbers of the cells were after 3 and 6 days are shown in Fig. 2. Cell proliferation rate was highest
$37^{\circ} \mathrm{C}$ and suppressed at both high and low temperatures.

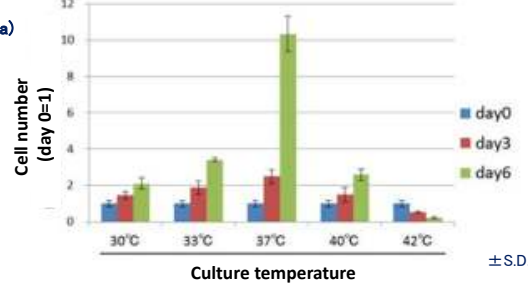

Fig. 2 Effects of temperature on the proliferation rate

(2) The expressions of redox-related genes at low culture temperatures

Dermal fibroblasts were cultured at 30,33 , or $37{ }^{\circ} \mathrm{C}$ for 24 hours. The expression levels of redox-related genes were quantified. The results for Heme Oxygenase $1(\mathrm{HO}-1)$, Thioredoxin Reductase 1 (TXNRD-1), NAD(P)H Quinone Dehydrogenase 1
(NOO1), Glutathione-Disulfide Reductase (GSR), Thioredoxin (TXN) are shown in Fig. 3. The expression levels of Nrf-2, the (TXN) are shown in Fig. 3. The expression levels of Nrf-2, the
transcription factor of these of redox-related genes, was also transcription factor of these of redox

As a result, the expressions of HO- 1 , TXNRD- 1 , NQO- 1 , and GSR $\mathrm{Nrf}-2$ also decreased in low temperatures.

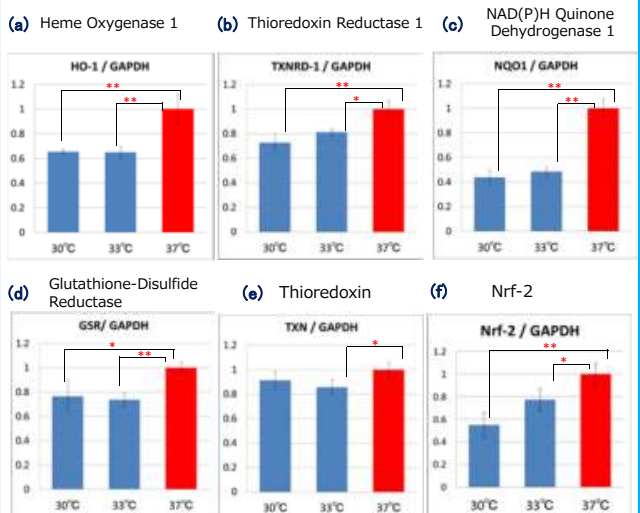

Fig. 3 The expression of redox-related gene under the culture at low temperatures

(3) Thioredoxin reductase activity at $30{ }^{\circ} \mathrm{C}$

Dermal fibroblasts were cultured at 30 or $37^{\circ} \mathrm{C}$ for 24 hours and then the activity levels of thioredoxin reductase was evaluated. The result showed that low temperature suppressed thioredoxin reductase at enzymatic activity level, as well as gene expression level (Fig. 4)

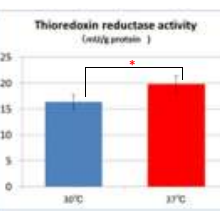

Fig. 4 Thioredoxin reductase activity of the dermal fibroblasts cultured at $30^{\circ} \mathrm{C}$ and $37^{\circ} \mathrm{C}$

\section{(4) Reactive oxygen species production}

Dermal fibroblasts were cultured at 30 or $37^{\circ} \mathrm{C}$ for 24 hours. $37^{\circ} \mathrm{C}$ and oxidative stress in the cells was measured by using CellROX green. ROS than the cells pre-cultured at $37^{\circ} \mathrm{C}$ (Fig. 5 )

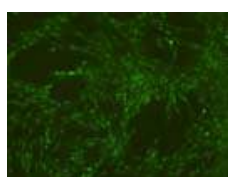

$30^{\circ} \mathrm{C}$

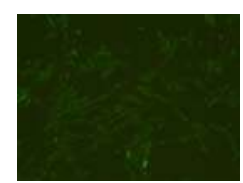

$37^{\circ} \mathrm{C}$
Fig. 5 Reactive oxygen species production of derma fibroblasts pre-cultured at $30^{\circ} \mathrm{C}$ and $37^{\circ} \mathrm{C}$

(5) Time -course analysis of redox-related gene expression in dermal fibroblasts after heating

Dermal fibroblasts were cultured for 24 hours at $33^{\circ} \mathrm{C}$, which is close to the normal skin surface temperature. Then culture close to the normal skin surface temperature. Then culture TXNRD-1, NQO1, TXN, and GSR were investigated over time. The results are shown in Fig. 6 .

The expression of $\mathrm{HO}-1$ kept increasing from the beginning. On the other hand, the expressions of TXNRD-1 and NQO1 decreased at first and recovered at around 6 hours, then increased at 12 hours. The expression of GSR kept decreased for more hours than TXNRD- 1 and NQO1. And the temperature shift had less effects on TXN.

Thus, time-course expression patterns for redox-related genes which were downstream genes of the same transcription factor $\mathrm{Nrf}-2$, were not the same.
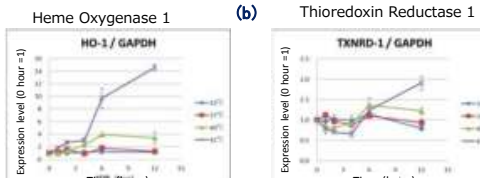
HO-2/6are 1

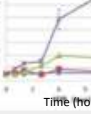
$\mathrm{NAD(P)H}$ Quinone
Dehydrogenase
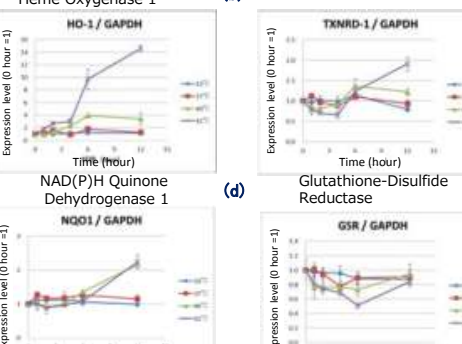<smiles>CCCC</smiles>
eductase

(e)

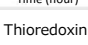

TEN/GAPOH
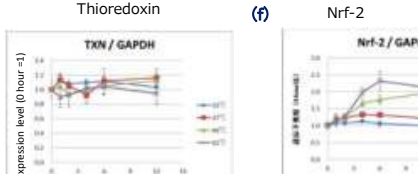

\section{Conclusions}

Gene expression of redox-related genes such as HO-1, TXNRD-1, and NOO- 1 decreased in low temperatures. Thioredoxin reductase activity also decreased in $30^{\circ} \mathrm{C}$ and ROS production increased in the cells pre-cultured at $30^{\circ} \mathrm{C}$. These results indicated that low temperature lowers the antioxidant capacity of dermal fibroblasts.

Because the expression of $\mathrm{Nrf}-2$ also change in temperature change, the expressional change of redox-related genes in change, the expressional change of redox-related genes in
temperature shift were thought to be caused by the change of temperature shift were

The time-course patterns of the expression of redox-related factors after heating are different. Other mechanisms than Nrf-2 also may be involved.

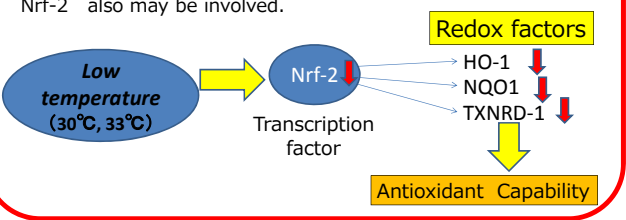

